技術報告

\title{
カードランの利用による冷凍加工豆腐及び 凍結乾燥豆腐の調製
}

\author{
中尾行宏* ・山口武信* ・田口哲也**
}

\author{
Preparations of Freezable Processed Tofu and Freeze-Dried \\ Tofu by Using Curdlan
}

\author{
Yukihiro NAKAO*, Takenobu YamaguCHI ${ }^{*}$ and Tetsuya TAGUCHI ${ }^{* *}$ \\ *Vitamin and Food Research Laboratories, Takeda Chemical Ind., Ltd. 17-85, \\ 2 cho-me, Juso-Honmachi, Yodogawa-ku, Osaka 532 \\ ** Takasago Plant, Takeda Chemical Ind., Ltd. 1-5, Aioi-machi, \\ Takasago-cho, Takasago-shi, Hyogo Pref. 676
}

\begin{abstract}
Traditional tofu is rarely used in frozen processed foods because its texture becomes sponge-like after freezing. Also, most available freeze-dried tofu lacks the desirable smooth and soft texture of traditional tofu. By using new ingredients and preparation methods with curdlan, thermogellabie $\beta-$ 1, 3-glucan produced by bacteria, practical preparation methods of freezable processed tofu and freeze-dried tofu were studied. Freezable processed tofu was prepared using an optimal formula of curdlan $1.2 \%$ and waxy corn starch $3 \%$ with a new preparation method. This freezable processed tofu was used in frozen foods such as Mabo-dofu (a Chinese dish of soybean curd with spicy minced meat), Agedashi dofu (deep-fried tofu in stock) and Miso soup, resulted in the smooth and soft texture like Kinugoshi tofu. Freeze-dried tofu was also prepared by an optimal formula of curdlan $0.5 \%$, waxy corn starch $1 \%$ and a controlled freezing condition. The resulting tofu had a smooth and soft texture after reconstitution with hot water.

(Received Jun. 16, 1993)
\end{abstract}

豆腐は冷凍処理すると, 逨り豆腐の例にみられるよう に組織がスポンジ様になり，豆腐特有のなめらかな食感 がなくなる，そのため冷涷食品などにはほとんど使用さ れていない，また，涷結乾燥豆腐は即席味噌汁などに使 用されているが，凍り豆腐に近い食感を呈するものが多 く改良が望まれる，冷凍豆腐の調製については，豆乳に 種々の添加物を加えるなどの特許出願122)がみられるが, 実用的な冷涷豆腐の調製に関してはほとんど報告されて いない，著者らは，カードランを用いてこれらの豆腐の 調製について検討した。 カードランはAlcaligenes faecalis var. myxogenes などの微生物が産生する $\beta-1,3$
ーグルコシド結合からなる加熱凝固性の多糖類である. この多糖類はその水臆濁液を $80^{\circ} \mathrm{C}$ 以上に加熱すると, 熱不可逆性のゲルを形成する ${ }^{3)}$. また， カードランゲル は冷凍耐性を有し ${ }^{4) 5}$ ，ゲルの離水防止にはでん粉の添加 が有効である(1)5).

本報では，カードランを利用して，絹ごし豆腐の食感 を呈する冷涷耐性のある加工豆腐及び凍結乾燥豆腐の実 用的な調製法について検討した結果，その製造法を確立 したので報告する。

*武田薬品工業(株)フード・ビタミン研究所（テ532 大阪市淀川区十三本町二丁目 17-85）

** 武田薬品工業(株)高仯工場（二676 高砂市高砂町相生町 1-5） 


\section{試料及ひ実験方法}

\section{1. 試 料}

カードランは武田薬品工業(株)より，ワキシーコーン スターチは日本食品化工(株)より，化工ワキシーコーン スターチ（サームフロ）は王子ナショナル(株)より，化 エワキシーコーンスターチ（オルスターチ W-3）はオル ガノ(株)より，豆腐用凝固剤（達人 No $5:$ グルコノデル タラクトン $64 \%$ ，塩化マグネシゥム $20 \%$ ，クエン酸ナト リウム $14 \%$ ，食品素材 $2 \%$ ）は理研ビタミン(株)上り
各々入手した，豆乳は豆腐製造メーカー（大阪市，沢商 店）から豆腐製造用の豆乳 (固形分約 13\%) を入手した。

\section{2. 冷凍加工豆腐の調製}

冷涷加工豆腐の調製法は以下のように行った，本報告 の\%は重量\%を示す.配合組成はカードラン 0.6 $1.4 \%$ ，豆乳（固形分 $10 \%$ に調整） $40 \sim 65 \%$ ，豆腐用凝固 剂 $0.4 \%$ (対豆乳)，でん粉 $0 \sim 4 \%$ ，水 $39.2 \sim 10.6 \%$ ，水 $20 \%$ である. 水に凝固剤, カードランを加え混合し $30^{\circ} \mathrm{C}$ に加温する。これに $80^{\circ} \mathrm{C}$ に加温した豆乳を加え混合す る（約 $60^{\circ} \mathrm{C}$ になる）。これに水とでん粉を加え，家庭用

\begin{tabular}{|c|c|c|c|c|}
\hline & & Sta & h(95 & \\
\hline & 0 & 2 & 3 & 4 \\
\hline $6^{0.6}$ & 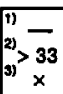 & $\begin{array}{c}53 \\
13 \\
\Delta\end{array}$ & $\begin{array}{c}42 \\
4.5 \\
\Delta\end{array}$ & $\begin{array}{c}41 \\
0.2 \\
\Delta \cdot x\end{array}$ \\
\hline 0.8 & $\underset{x}{>28}$ & $\begin{array}{c}75 \\
12 \\
\Delta\end{array}$ & $\begin{array}{c}73 \\
4.0 \\
0\end{array}$ & $\begin{array}{c}60 \\
0 \\
\Delta-x\end{array}$ \\
\hline 1.0 & $\begin{array}{c}175 \\
>23 \\
x\end{array}$ & $\begin{array}{l}112 \\
8.5 \\
0 . \Delta\end{array}$ & $\begin{array}{c}100 \\
3.6 \\
0\end{array}$ & $\begin{array}{c}90 \\
0.5 \\
\Delta-x\end{array}$ \\
\hline
\end{tabular}

(Soy milk 40\%)
$\operatorname{Starch}(\%)$

\begin{tabular}{|c|c|c|c|}
\hline 0 & 2 & 3 & 4 \\
\hline$>28$ & 55 & 46 & 45 \\
$x$ & 11 & 3.5 & 0 \\
\hline- & 79 & $\Delta$ & $\Delta-x$ \\
$>23$ & 9.4 & 34 & 70 \\
$x$ & $\Delta$ & 0 & 0 \\
\hline 160 & 110 & 100 & 93 \\
$>20$ & 7.6 & 2.8 & 0 \\
$x$ & $0-\Delta$ & 0 & $\Delta-x$ \\
\hline
\end{tabular}

(Soy milk 50\%)
$\operatorname{Starch}(\%)$

\begin{tabular}{|c|c|c|c|}
\hline \multicolumn{1}{c}{0} & \multicolumn{1}{c}{2} & \multicolumn{1}{c}{3} & 4 \\
\hline$>24$ & 57 & 48 & 56 \\
$x$ & 8.3 & 2.2 & 0 \\
& $x$ & $\Delta-x$ & $\Delta-x$ \\
\hline 66 & 84 & 71 & 78 \\
$>19$ & 6.8 & 1.9 & 0 \\
$x$ & $\Delta$ & $\Delta$ & $\Delta-x$ \\
\hline 152 & 110 & 99 & 95 \\
$>16$ & 6.0 & 1.6 & 0 \\
$x$ & $\Delta$ & $0-\Delta$ & $\Delta-x$ \\
\hline
\end{tabular}

(Soy milk 65\%)

Fig. 1 Effects of curdlan and starch on the properties of freezable processed tofu

${ }^{1)}$ Gel strength $\left(\mathrm{g} / \mathrm{cm}^{2}\right){ }^{2)}$ Syneresis (\%)

3) Texture : (), smooth, Kinugoshi tofu-like ; $\bigcirc$, soft-Momen tofu-like ; $\triangle$, slightly different from tofu; $\times$, completely different from tofu

Bold line indicates the range of samples with acceptable texture.

Table 1 Effects of the variety of starch and curdlan on the properties of freezable processed tofu

\begin{tabular}{|c|c|c|c|c|c|}
\hline $\begin{array}{l}\text { Variety } \\
\text { of starch }\end{array}$ & Curdlan & $\begin{array}{l}\text { Gel strength } \\
\left(\mathrm{g} / \mathrm{cm}^{2}\right)\end{array}$ & $\begin{array}{l}\text { Syneresis } \\
(\%)\end{array}$ & $\begin{array}{c}\text { Texture } \\
\text { (served cold) }\end{array}$ & $\begin{array}{c}\text { Texture } \\
\text { (served hot) }\end{array}$ \\
\hline Modified corn starch & 0.8 & 98 & 5.2 & soft-Momen tofu-like & soft, fairly sticky \\
\hline \multirow[t]{2}{*}{ (Thermo FLO) } & 1.0 & 120 & 4.8 & $\begin{array}{l}\text { Momen tofu-like } \\
\text { slightly too elastic }\end{array}$ & $\begin{array}{l}\text { Momen tofu-like } \\
\text { slightly sticky }\end{array}$ \\
\hline & 1.2 & 148 & 4.6 & too elastic, gel-like & $\begin{array}{l}\text { Momen tofu-like } \\
\text { slightly sticky }\end{array}$ \\
\hline $\begin{array}{l}\text { Modified corn starch } \\
\text { (OL starch W-3) }\end{array}$ & 0.8 & 98 & 9.0 & Momen tofu-like & soft, fairly sticky \\
\hline \multirow[t]{3}{*}{ Waxy corn starch } & 0.8 & 90 & 3.0 & $\begin{array}{l}\text { smooth, Kinugoshi } \\
\text { tofu-like }\end{array}$ & soft, fairly sticky \\
\hline & 1.0 & 128 & 4.0 & $\begin{array}{l}\text { Kinugoshi tofu-like } \\
\text { slightly too elastic }\end{array}$ & $\begin{array}{l}\text { Kinugoshi tofu-like } \\
\text { slightly sticky }\end{array}$ \\
\hline & 1.2 & 150 & 4.6 & too elastic, gel-like & $\begin{array}{l}\text { smooth, Kinugoshi } \\
\text { tofu-like }\end{array}$ \\
\hline
\end{tabular}

Tofu ingredients : Soy milk (solid content $10 \%$ ) $50 \%$, starch $3 \%$, coagulant $0.2 \%$, water and ice remainder. 
ミキサー（日立 VA-W 26）で約 3 分間 $40^{\circ} \mathrm{C}$ 以下で均質 化する.この留濁液を真空下で脱気した後, 直径 $3 \mathrm{~cm}$ のケーシングチューブ又はステンレスのトレー（綐 25 $\mathrm{cm}$, 横 $17 \mathrm{~cm}$, 高さ $1 \mathrm{~cm}$ ) に充樭し, 30 分間蒸煮した. 冷却後急速冷凍機（高橋工業製 TBY-10R 型，バッ千式 フリーザー)を用いて, $-35^{\circ} \mathrm{C}$ で冷凍した後, $-18^{\circ} \mathrm{C}$ の フリーザーで 7 日間冷凍保存した。

\section{3. 凍結乾燥豆腐の調製}

冷涷豆腐の調製法に準じて豆腐を調製する，但し，充 塄容器はステンレス製トレー $(17 \times 25 \times 1 \mathrm{~cm})$ を用い た. 得られた豆腐をトレー内で, 繸横 $1 \mathrm{~cm}$ 角に切断し, $-20^{\circ} \mathrm{C}$ で予備凍結後, FREEZE DRYER FD-1（東京理 科機械）により凍結乾燥した。

\section{4. 豆腐のゲル強度の测定}

冷涷加工豆腐を解凍した後，約 $20^{\circ} \mathrm{C}$ に保持する. 豆腐 は高さ $2 \mathrm{~cm}$, 直径 $3 \mathrm{~cm}$ に切断したものを試料とし、レ オメーターCR-200D (サン科学) を用い, 直径 $1 \mathrm{~cm} の$ 円柱プランジャー，架台スピード $1 \mathrm{~cm} / \mathrm{sec} て ゙$ 破断強度 を測定し，単位面積当たりの強度をゲル強度 $\left(\mathrm{g} / \mathrm{cm}^{2}\right)$ とした.

5. 豆腐の離水率の測定

冷涷加工豆腐を解凍した後，ケーシングチューブから全 量を取り出して秤量し，そこからゲルを引き上げて除い た残量を離水量とした．離水率（\%）は全重量に対する 離水量の百分率で表示した。

\section{6. 走查型電子顥徽鏡による観察}

倲結乾燥豆腐を液体堂素で涷結して，割断して武料の 断面を観察した，白金・パラジゥムでコーティングした 後, 日立FESEM S-800 走查型電子顕微鏡で観察した。

\section{7. 官能評価}

トレーに充填して調製した冷凍加工豆腐を解凍した後 $3 \mathrm{~cm}$ 角に切り, 冷時に, 又は沸滕水中で 5 分間加熱して 温時に，オープンパネル法で外観, 風味, 食感を評価し た，また，豆府入り冷凍食品は加熱した後，同様に評価 した.

\section{8. 豆腐使用冷凍食品の調製}

調製した冷凍前の加工豆腐を使用し，常法通り麻婆豆 腐，揚げだし豆腐，豆腐とアスパラガス入りスープ，味

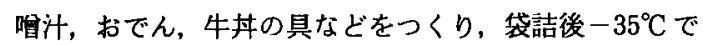
冷涷して， $-18^{\circ} \mathrm{C}$ のリーザーで保存した。

\section{実験結果および考察}

1. 冷凍加工豆腐の品質に及ぼす豆乳，カードラン， でん粉の影笠
冷凍加工豆腐の品質に及ぼす豆乳，カードラン，でん 粉の影響を検討した。豆乳（固形分 $10 \%$ に調整）含量 $40 \% ， 50 \% ， 65 \%$ にっいて，カードラン含量 $0.6 \%$, $0.8 \%, 1.0 \%$ ，でん粉（サームフロ）含量 $0 \%, 2 \%, 3 \%$, 4\%をかえ，それぞれ冷凍加工豆腐を調製した。冷凍加工 豆腐を解凍して評価した結果を Fig. 1 に示す。でん粉含 量が多いほど豆腐の離水が減少し，カードラン含量が多 いほど豆腐のゲル強度が高くなる，豆腐の離水が少な く, 食感の良い範囲を求めると，太線の範囲になる，豆 乳含量 $40 \%$ と $50 \%$ ではほぼ同じ結果であるが，豆乳 $40 \%$ の方が豆腐の風味が弱く，豆乳 $65 \%$ の場合には食 感の適性範囲が狭くなる。ここらの結果より, 暫定組成 として豆乳 50\%，カードラン $0.8 \sim 1.0 \%$ ，でん粉 2 3\% の配合をきめた。

2. 冷凍加工豆腐の品質に及ぼすでん粉の種類, カー ドランの影響

冷凍加工豆腐の品質に及代すでん粉の種類及びカード ラン含量の影響をTable 1 に示す. 豆腐のゲル強度はで ん粉の種類により差がないが，離水は若干差があった。 これらのでん粉の中では，ワキシーコーンスターチは豆 腐の離水が少なく，食感が良好であった。カードラン含 量は冷凍加工豆腐の解凍品の食感加ら判断すると $0.8 \%$ であるが，冷凍加工豆腐は調理食品に利用した場合，通 常加熱して温加い状態で食べることになるので，加熱品 の食感の評価を重視すればカードランは $1.2 \%$ が適当と なる. 以上の結果より, 冷涷加工豆腐の標準組成は豆乳

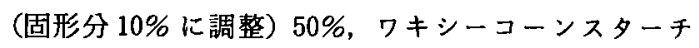
$3 \%$ ，カードラン $1.2 \%$, 豆腐用凝固剂 $0.2 \%$, 水 $25.6 \%$, 水 $20 \%$ が適当である。

また，加工豆腐の凝固性に及ぼすカードラン含量の影 響及び冷凍前後の物性を市販豆腐も含めて Table 2 に 示す. 加工豆腐の凝固はカードランによること，冷涷・ 解凍後の豆腐の物性は, 従来の市販品ではスポンジ様に なるが，本加工豆腐では冷凍前とほとんど同じであるこ とが確認された。

冷東加工豆腐の調製は豆乳をカードランで豆腐状に固 めて, カードランゲルの離水防止にでん粉を使用する. カードランゲルは冷谏耐性があるので，加工豆腐を冷凍 しても物性の変化は少ないあのと推察される.

\section{3. 豆腐使用冷凍食品}

加工豆腐を使用した麻婆豆腐, 揚げだし豆腐, 豆腐之 アスパラガス入りスープ, 味蜾汁, おでん，牛事の具の 冷凍食品を加熱して官能評価したおでん，牛井の具の ような比較的大きな形状の豆腐では，冷凍していない現 
Table 2 Effects of curdlan on the coagulation and freezing-thawing of processed tofu

\begin{tabular}{|c|c|c|c|}
\hline \multirow{2}{*}{$\begin{array}{c}\text { Curdlan }^{1)} \\
(\%)\end{array}$} & \multicolumn{3}{|c|}{ Before freezing } \\
\hline & $\begin{array}{l}\text { Gel strength } \\
\left(\mathrm{g} / \mathrm{cm}^{2}\right)\end{array}$ & $\underset{\text { strain }(\mathrm{mm})}{\text { Breaking }}$ & Texture \\
\hline 0 & \multicolumn{2}{|c|}{ not gelled (paste) } & \\
\hline 0.4 & 23 & 6.0 & too soft, sticky \\
\hline 0.8 & 53 & 6.0 & Kinugoshi tofu-like, slightly soft \\
\hline 1.2 & 101 & 5.8 & Kinugoshi tofu-like, slightly hard \\
\hline traditional Kinugoshi tof ${ }^{2)}$ & 70 & 8.4 & Kinugoshi tofu-like \\
\hline traditional Momen tofu ${ }^{2)}$ & 125 & 10.2 & Momen tofu-like \\
\hline
\end{tabular}

1) Tofu ingredients : Soy milk (solid content $10 \%$ ) 50\%, waxy corn starch $3 \%$, coagulant $0.2 \%$, water and

2) Manufactured by Sanyo Food Co. (Nara Pref.).

Table 3 Effects of curdlan and starch on the properties of freeze-dried tofu

\begin{tabular}{|c|c|c|c|}
\hline \multicolumn{2}{|c|}{ Ingredients of tofu ${ }^{1)}(\%)$} & \multicolumn{2}{|c|}{ Properties of freeze-dried tof $\mathrm{u}^{2)}$} \\
\hline Curdlan & $\begin{array}{l}\text { Waxy corn } \\
\text { starch }\end{array}$ & Reconstitution & Texture \\
\hline 1.2 & 3.0 & slow & not completely reconstituted \\
\hline 0.8 & 3.5 & slow & not completely reconstituted \\
\hline 1.0 & 1.0 & considerably slow & not completely reconstituted \\
\hline 0.8 & 2.0 & fairly slow & not completely reconstituted \\
\hline 0.8 & 1.0 & fairly slow & slightly grainy \\
\hline 0.5 & 2.0 & fairly slow & starchy \\
\hline 0.5 & 1.0 & fast (good) & considerably smooth \\
\hline 0.5 & 0.5 & fast (good) & grainy \\
\hline 0.5 & 1.5 & slightly slow & slightly starchy \\
\hline
\end{tabular}

${ }^{1)}$ Soy milk (solid content $10 \%$ ) $50 \%$, coagulant $0.2 \%$, water and ice remainder.

${ }^{2)}$ Evaluated by sensory test after standing for $3 \mathrm{~min}$ in the addition of boiled water to freeze-dried tofu.

行豆腐と比較すると少る。しかし, 麻婆豆腐, 豆腐と了 スパラガス入りスープ，味噌汁など小さな形状で使用す る豆腐や揚げだし豆腐のような豆腐を加工する場合に は, 冷凍後であ絹ごし豆腐様の食感を呈し冷凍食品とし て利用できる品質である.

\section{4. 凍結乾蜗豆腐の品質に及ほす豆腐の組成の影響}

冷凍加工豆腐の組成と凍結乾燥豆腐の品質を Table 3 に示す．予備凍結は $-20^{\circ} \mathrm{C}$ である。冷凍加工豆腐として 食感が良好な組成では, 凍結乾燥豆腐の組織が維密にな り，湯もどしによる復元が困難であった。 そこで、湯も どりの速い製品を調製するために，若干冷凍変性する組 成で多孔質の乾燥品をつくり，湯むどしした時点で滑ら かな食感になる組成の検討をおこなった，カードラン， ワキシーコーンスターチの配合を减少させて検討した結
果, 豆乳 $50 \%$, カードラン 0.5\%，ワキシーコーンスター チ $1.0 \%$ の系で湯もどりが容易で, 食感の滑らかな凍結

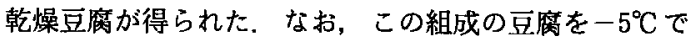
60 分間予備凍結して凍結乾燥した場合には，禓もどりは 非常に速くなるが，凍り豆腐様の食感になり好ましくな い.したがって，冷凍条件と組成は組み合わせて考える 必要がある.

\section{5. 凍結乾燥豆腐の品質に及ぼす冷凍条件の影響}

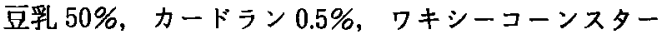
チ $1 \%$ 配合の豆腐の組成で，ステンレストレーに成型 し, 冷凍能力 $6000 \mathrm{cal} / \mathrm{hr}$ の急速冷凍機で設定温度を -5 $\sim-35^{\circ} \mathrm{C}$ に変化させて冷凍した後, 東結乾燥した. 結果 を Table 4 に示す. $-5^{\circ} \mathrm{C}$ の冷涷では, 製品の表面が荒 れてポーラスになる。したがって，湯もどりは非常に速 


\begin{tabular}{cccl}
\hline \multicolumn{3}{c}{ After freezing-thawing } \\
\hline $\begin{array}{c}\text { Gel strength } \\
\left(\mathrm{g} / \mathrm{cm}^{2}\right)\end{array}$ & $\begin{array}{c}\text { Breaking } \\
\text { strain }(\mathrm{mm})\end{array}$ & $\begin{array}{c}\text { Syneresis } \\
(\%)\end{array}$ & \multicolumn{1}{c}{ Texture } \\
& & & \\
21 & 6.0 & trace & too soft, sticky \\
51 & 6.0 & 2.5 & Kinugoshi tofu-like, slightly soft \\
100 & 6.0 & 2.6 & Kinugoshi tofu-like, slightly hard \\
\hline 265 & 14.6 & 24.2 & sponge-like \\
415 & 26.2 & 19.2 & sponge-like \\
\hline
\end{tabular}

ice remainder.

Table 4 Effects of the freezing condition on the properties of freeze-dried tofu

\begin{tabular}{cclcl}
\hline \hline $\begin{array}{c}\text { Freezing } \\
\text { condition }\end{array}$ & $\begin{array}{c}\text { Time to } \\
\text { be frozen } \\
\text { (min) }\end{array}$ & \multicolumn{1}{c}{$\begin{array}{c}\text { Appearance } \\
\text { (dry) }\end{array}$} & $\begin{array}{c}\text { Time to be } \\
\text { reconstituted } \\
\text { with hot water }\end{array}$ & \multicolumn{1}{c}{$\begin{array}{c}\text { Texture } \\
\text { (rehydrated) }\end{array}$} \\
\hline$-5^{\circ} \mathrm{C}$ & 60 & rough surface, porous & instantaneous & grainy, slightly Kori-dofu-like \\
$-10^{\circ} \mathrm{C}$ & 45 & fairly rough surface, fairly porous & about $0.5 \mathrm{~min}$ & slightly grainy \\
$-20^{\circ} \mathrm{C}$ & 30 & slightly rough surface, slightly porous & 1 & smooth \\
$-30^{\circ} \mathrm{C}$ & 15 & smooth surface & 2 & smoother \\
$-35^{\circ} \mathrm{C}$ & 13 & smooth surface & 2 & smoother \\
\hline
\end{tabular}

Tofu ingredients : Soy milk (solid content $10 \%$ ) $50 \%$, curdlan $0.5 \%$, waxy corn starch $1 \%$, coagulant $0.2 \%$, water and ice $48.3 \%$.

くなるが，食感はやや東り豆腐様になり好ましくない， また， $-30^{\circ} \mathrm{C}$ 以下の冷凍条件では冷涷変性が小さく，緻 密な組織になり，湯もどりがやや遅く好ましくない，最 適冷凍条件は約 30 分で東結が完了する $-20^{\circ} \mathrm{C}$ 設定であ り, 湯もどりが速く, 食感も滑らかな製品が得られた。 以上の結果より，標準製造法は豆乳 50\%，カードラン

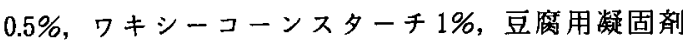
$0.2 \%$, 水 $28.3 \%$, 水 $20 \%$ の組成で, $-20^{\circ} \mathrm{C}$ で急速冷涷し て凍結乾燥するのが適当である.なお，別途検討した結 果では, 同じ予備凍結条件であれば,カードラン含量 0.5 〜 0.7\%，ワキシーコーンスターチ 0.8 1.2\%の範囲で殆 ど同じ品質の製品が得られた．凍結乾燥豆腐の冷凍曲線 を Fig. 2 に示す. 最大水結晶の成長領域である $0^{\circ} \mathrm{C} \sim-$ $5^{\circ} \mathrm{C}$ の領域を通過する時間は $-35^{\circ} \mathrm{C}$ の冷凍では約 10 分, $-20^{\circ} \mathrm{C}$ では約 20 分, $-5^{\circ} \mathrm{C}$ では約 50 分かかっている. したがって，それぞれ氷結晶の成長が異なり，乾燥した とき組織の密度に違いが生じることが推察される。

$-5^{\circ} \mathrm{C},-20^{\circ} \mathrm{C},-35^{\circ} \mathrm{C}$ でそれぞれ冷東した凍結乾燥 豆鹰の電子顕微鏡写真を Fig. 3 に示す. 各冷凍温度によ
り組織の違いがはっきりし，穴の大きいものほぞ湯もど りが容易であるが,ざらつきとなって食感に現れる。

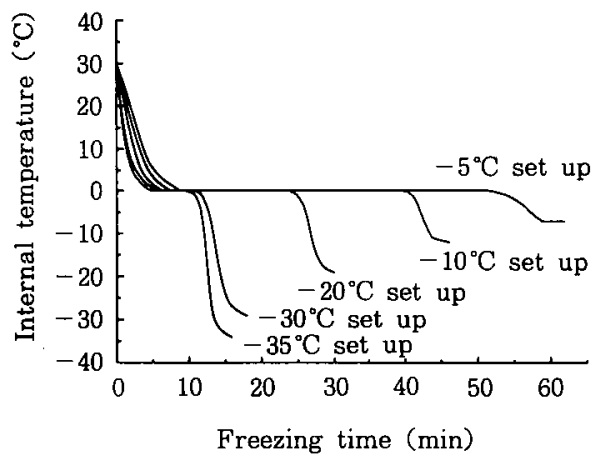

Fig. 2 Internal temperature of freeze-dried tofu on the freezing

Tofu for freeze-drying : $17 \times 25 \times 1 \mathrm{~cm}$ (stuffed into stainless mold). Freezer: Air blast (Takahashi Ind., Ltd. type TBY-10R). 


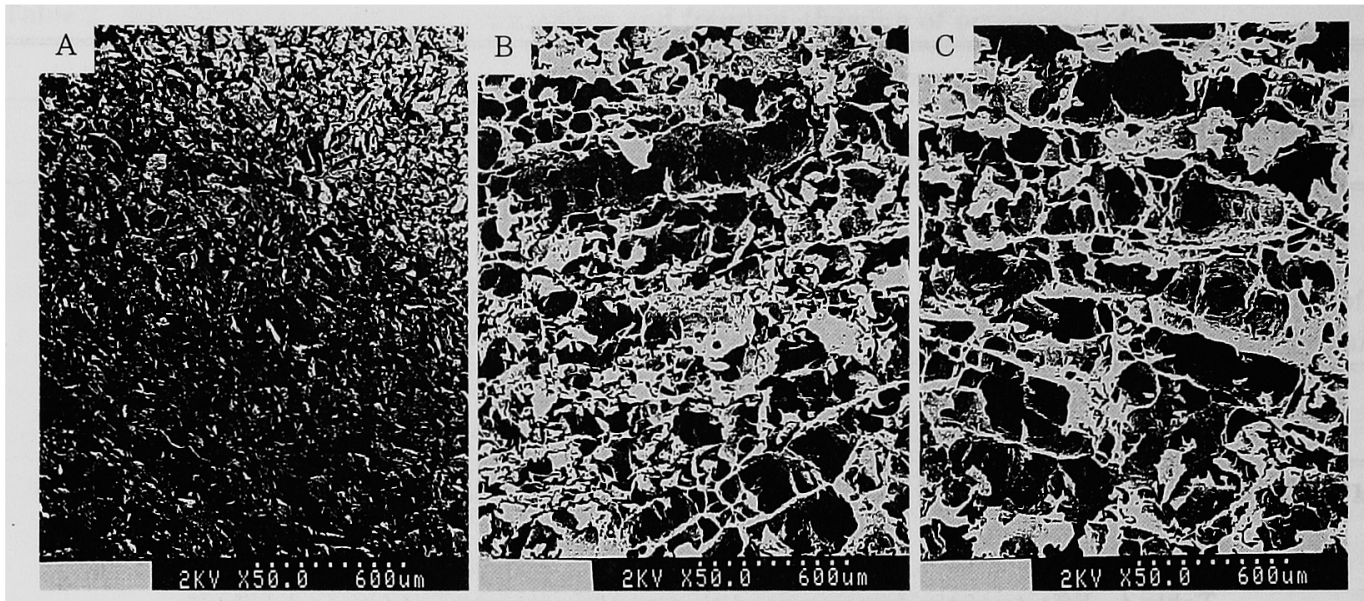

Fig. 3 Scanning electron micrographs of freeze-dried tofu $(\times 50)$

$\mathrm{A},-35^{\circ} \mathrm{C}$ freezing ; $\mathrm{B},-20^{\circ} \mathrm{C}$ freezing ;,$-5^{\circ} \mathrm{C}$ freezing
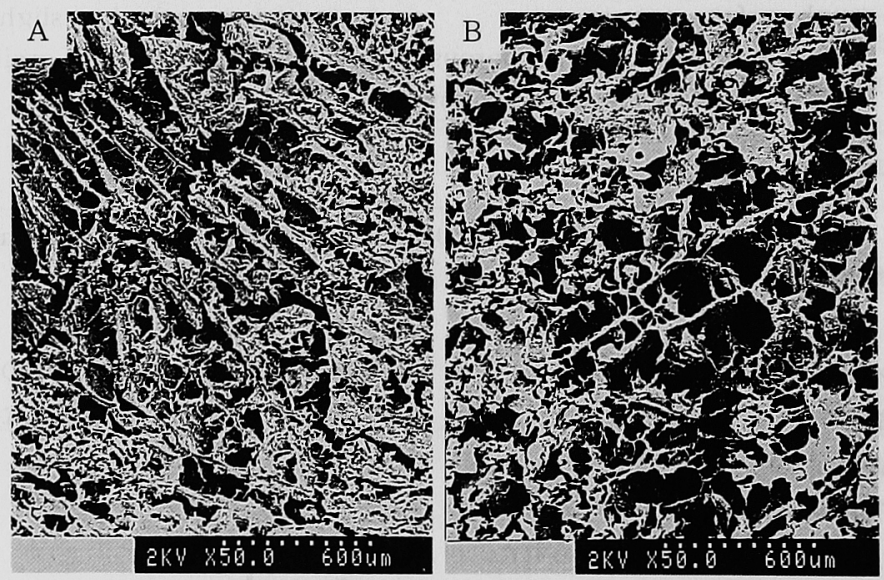

Fig. 4 Scanning electron micrographs of freeze-dried tofu $(\times 50)$

A, conventional freeze-dried tofu ; B, freeze-dried tofu with curdlan

カードラン利用凍結乾燥豆腐と市販凍結乾燥豆腐（1 例）の電子顕微鏡写真を Fig.4に示す，市販品は層状の 組織で, 厚い膜をしている.この厚い膜が食感のざらつ きとして現れることが推祭される.一方，カードラン利 用凍結乾操豆腐は膜厚が薄く均一な組織をしているた め, 滑らかな食感になることが推察される.

要約

カードランを利用して，絹ごし豆腐様の食感を呈する 冷東耐性のある加工豆腐及び凍結乾燥豆腐の実用的な調
製法について検討した。

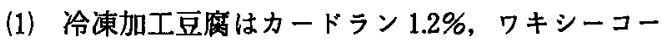
ンスターチ $3 \%$ を用いた最適配合組成で，カードランに 適した調製法により調製できた。

（2）冷凍加工豆腐は麻婆豆腐，揚げだし豆腐，味㽞汁， スープなどの冷凍食品に使用すると，絹ごし豆腐様の滑 らかな，やわらかい食感を呈し利用できた。

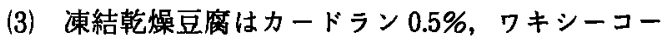
ンスターチ $1 \%$ を用いた配合組成で，冷凍条件を選択す ることにより，製造法を確立した。 


\section{文献}

1）荒田勇二・高垣康雄：公開特許公報 平 1179659 .

2）藤村牧範：公開特許公報 平 4-88959.

3) Maeda, I., Saito, H., Masada, M., Misaki, A. and Harada, T. : Agric. Biol. Chem., 31, 1184 (1967).
4）高橋 央 - 原田篤也：家政学雑誌，37, 251 (1986).

5) NaKaO, Y., Konno, A., Taguchi, T., Tawada, T., Kasal, H., Toda, J. and Terasaki, M. : J. Food Sci., 56, 769 (1991).

（平成 5 年 6 月 16 日受理） 